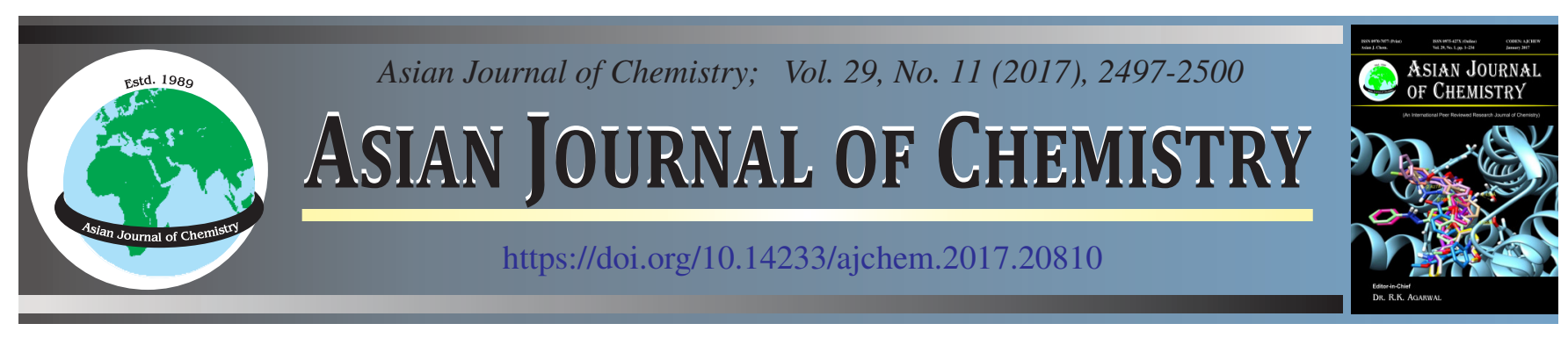

\title{
High Performance Liquid Chromatographic Method for Simultaneous Quantification of Naloxone and Oxycodone
}

\author{
Pallapati Suman ${ }^{1,2, *}$, Tirukkovalluri Siva RaO ${ }^{1}$ and Kallam Venkata Siva Rama Krishna Reddy ${ }^{2}$
}

${ }^{1}$ Department of Inorganic \& Analytical Chemistry, Andhra University, Visakhapatnam-530 003, India

${ }^{2}$ Laurus Labs Limited, Visakhapatnam-531 021, India

*Corresponding author: E-mail: pallapatisumanphd@gmail.com

Received: 24 May 2017;

Accepted: 28 July 2017;

Published online: 29 September 2017;

AJC-18580

\begin{abstract}
High performance liquid chromatography was applied to the simultaneous determination of naloxone and oxycodone. The method depends on separation and analysis of naloxone and oxycodone using C18 analytical column $(250 \times 4.6 \mathrm{~mm}, 5 \mu \mathrm{m})$. The mobile phase consists of a mixture of potassium dihydrogen phosphate $(\mathrm{pH} 5.5 ; 0.1 \mathrm{M})$ and acetonitrile $(70: 30, \mathrm{v} / \mathrm{v})$. The photodiode array detector was set at 210 $\mathrm{nm}$. The retention times of naloxone and oxycodone were 2.893 and $4.946 \mathrm{~min}$, respectively. The total run time was 6 min. The developed method was validated as per the guidelines of International Conference on Harmonization and successfully applied to the simultaneous determination of naloxone and oxycodone in their tablets. All the results of validation parameters were acceptable and confirmed that the method is appropriate for the estimation of naloxone and oxycodone simultaneously.
\end{abstract}

Keywords: Naloxone, Oxycodone, HPLC, Diode array detector.

\section{INTRODUCTION}

Naloxone is a competitive opioid antagonist used for the reversal of post-operative respiratory depression, reversal of respiratory and central nervous system depression from opioid administration during labour and child birth [1,2]. Naloxone reverses the effect of opioid by removing the opioid from the receptors for a short term and thus assists in the restoration of breathing [3]. Naloxone is a derivative of thebaine and chemically described as (4R,4aS, 7aR, 12bS)-4a,9-dihydroxy-3-prop2-enyl-2,4,5,6,7a,13-hexahydro-1H-4,12-methano benzofuro[3,2-e]isoquinoline-7-one (Fig. 1).

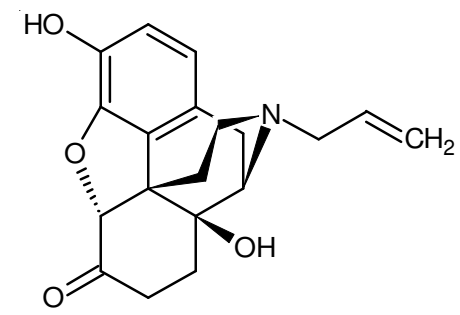

Fig. 1. Chemical structure of naloxone

Oxycodone is an opioid agonist with analgesic activity used in the treatment of moderate to severe pain [4]. Oxycodone exhibits its analgesic activity by binding to the $\mu-$ receptors in the central nervous system and thus imitating the effects of endogenous opioids [5]. Oxycodone inhibits the release of dopamine, substance $\mathrm{P}, \gamma$-aminobutyric acid, acetylcholine and noradrenaline [6]. Oxycodone is a semisynthetic derivative of codeine and chemically described as (4R,4aS,7aR,12bS)-4a-hydroxy-9-methoxy-3-methyl-2,4,5, 6,7a,13-hexahydro-1H-4,12-methanobenzofuro[3,2-e]isoquinoline-7-one (Fig. 2).

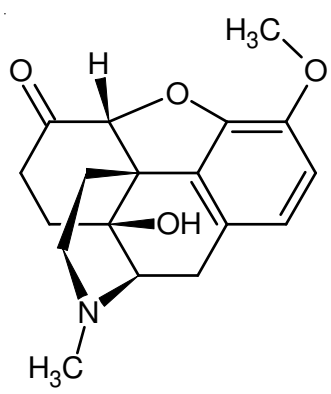

Fig. 2. Chemical structure of oxycodone

The US Food and Drug Administration has approved naloxone and oxycodone combination as prolonged-release tablets for the treatment of severe pain that can be satisfactorily managed only with opioid pain relievers [7]. In the combination tablet, oxycodone exhibits pain killing effect and naloxone is responsible to bring relief from constipation which is a common side effect of treatment with strong pain relievers [8]. 
The combination of naloxone and oxycodone is not official in any pharmacopoeia. No analytical methods are found in the literature for the simultaneous determination of naloxone and oxycodone. But many research reports are available in the literature for the determination of naloxone and oxycodone individually. There are few reports published regarding the determination of naloxone in microparticles, transdermal formulation, plasma and pharmaceutical dosage form. Naloxone has been determined by spectrophotometry [9], HPLC [9-12] and LC-MS [13,14] methods. HPLC [15], HPTLC [16], LCMS [17-19], GC-MS [20,21] and capillary electrophoresis [22] methods have been adapted to the determination of oxycodone in biological samples like human blood, plasma, urine and in oral pharmaceutical solutions. Therefore, the present study was aimed to develop and validate a HPLC assay method for simultaneous quantification of naloxone and oxycodone in bulk and combined tablet dosage

\section{EXPERIMENTAL}

The chromatographic separation followed by photodiode array detection were achieved by employing Waters 2695 alliance HPLC system with Waters 2998 photo diode array detector. Waters Empower2 software was used to control the instrument and process the data. The Waters 2695 alliance HPLC system used in the analysis comprised an autosampler injector, binary pump and column heater.

Naloxone and oxycodone reference standards were obtained from Lara Drugs Private Limited (Telangana, India). Targinact tablets (Napp Pharmaceuticals Limited, Cambridge, UK) labeled to contain $10 \mathrm{mg}$ naloxone and $20 \mathrm{mg}$ oxycodone was employed. Milli-Q water (Millipore, USA) was used all through the experiments. Potassium dihydrogen phosphate and orthophosphoric acid of analytical grade were acquired from Sd. Fine Chemicals Ltd., Mumbai, India. HPLC grade acetonitrile was from Merck India Ltd (Mumbai, India).

Chromatographic conditions: The chromatographic conditions maintained were Thermo C18 $(250 \mathrm{~mm} \times 4.5 \mathrm{~mm}$ i.d., particle size $5 \mu \mathrm{m}$ ) analytical column as stationary phase, column temperature of $25 \pm 2{ }^{\circ} \mathrm{C}, 0.1 \mathrm{M}$ potassium dihydrogen phosphate: acetonitrile (70:30 v/v, pH 5.5 adjusted with orthophosphoric acid) as mobile phase, flow rate of $1 \mathrm{~mL} / \mathrm{min}, 10 \mu \mathrm{L}$ of injection volume and wavelength $210 \mathrm{~nm}$ as detection analytical wavelength. The mobile phase was filtered through $0.45 \mu \mathrm{m}$ pore size membrane filter and sonicated for $20 \mathrm{~min}$ before analysis.

Stock standard solution: $10 \mathrm{mg}$ of naloxone and $20 \mathrm{mg}$ of oxycodone were weighed accurately, dissolved and diluted with mobile phase in a $100 \mathrm{~mL}$ volumetric flask to obtain the final concentration of $100 \mu \mathrm{g} / \mathrm{mL}$ of naloxone and $200 \mu \mathrm{g} / \mathrm{mL}$ of oxycodone. The stock solution was stored at $2-8{ }^{\circ} \mathrm{C}$.

Working standard solutions: The working standard solutions were prepared by diluting the above standard stock solution with mobile phase to reach a concentration range of $5-15 \mu \mathrm{g} / \mathrm{mL}$ for naloxone and $10-30 \mu \mathrm{g} / \mathrm{mL}$ for oxycodone.

Construction of calibration curve for naloxone and oxycodone: $10 \mu \mathrm{L}$ of working standard solution was injected into the HPLC system three times for each concentration and chromatographed using the chromatographic conditions mentioned above. Using least-squares linear regression analysis, calibration curves were generated by plotting the peak area $v s$. concentration of the analyte.

Tablet sample preparation: Ten tablets were weighed and powdered. An accurate weight of the powder equivalent to $10 \mathrm{mg}$ naloxone and $20 \mathrm{mg}$ oxycodone was transferred into a $100 \mathrm{~mL}$ volumetric flask and extracted with $30 \mathrm{~mL}$ of mobile phase in an ultrasonic bath for $30 \mathrm{~min}$. The solution thus prepared were diluted to volume with the mobile phase then filtered through a $0.45 \mu \mathrm{m}$ pore size membrane filter.

Assay of naloxone and oxycodone in tablet dosage form: $1 \mathrm{~mL}$ of above prepared tablet sample solution was diluted to $10 \mathrm{~mL}$ with mobile phase in a $10 \mathrm{~mL}$ volumetric flask to prepare tablet sample solution containing $10 \mu \mathrm{g} / \mathrm{mL}$ of naloxone and $20 \mu \mathrm{g} / \mathrm{mL}$ of oxycodone. Solution prepared was filtered using $0.45 \mu \mathrm{m}$ pore size membrane filter and then analyzed as mentioned under the construction of calibration curve for naloxone and oxycodone.

\section{RESULTS AND DISCUSSION}

Method development: By using a Thermo C18 column $(250 \times 4.6 \mathrm{~mm}, 5 \mu \mathrm{m})$ with temperature $25 \pm 2{ }^{\circ} \mathrm{C}$, sharp peaks of naloxone and oxycodone with satisfactory separation were achieved. Hence the same column and temperature was used in the present study. To achieve good peak shape and resolution under isocratic conditions, mixtures of acetonitrile and $0.1 \mathrm{M}$ potassium dihydrogen phosphate in different combinations with different flow rates and $\mathrm{pH}$ were tried as mobile phase on a Thermo C18 column. Finally, a binary mixture of $0.1 \mathrm{M}$ potassium dihydrogen phosphate (pH 5.5 adjusted with orthophosphoric acid) and acetonitrile in 70:30 v/v proportions with a flow rate of $1 \mathrm{~mL} / \mathrm{min}$ was found to be the suitable of all combinations. Injection volume as $10 \mu \mathrm{L}$ was appropriate in separating naloxone and oxycodone. Wavelength of $210 \mathrm{~nm}$ was chosen for the simultaneous determination of naloxone and oxycodone with good sensitivity. Under the optimized chromatographic conditions, the retention time of $2.893 \mathrm{~min}$ and $4.946 \mathrm{~min}$ was obtained for naloxone and oxycodone, respectively (Fig. 3).

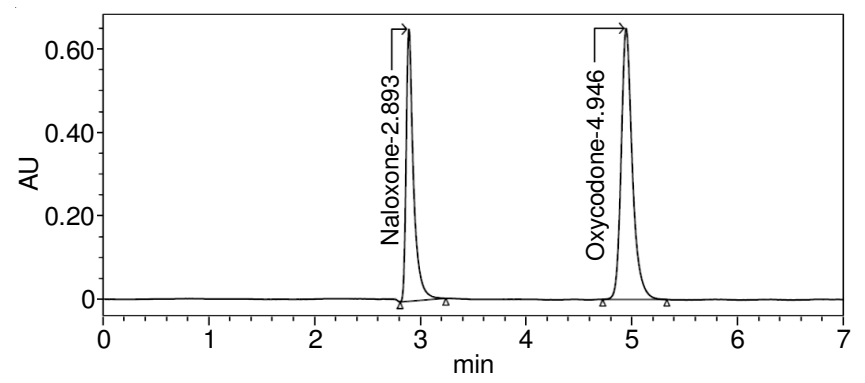

Fig. 3. Typical chromatogram of naloxone $(10 \mu \mathrm{g} / \mathrm{mL})$ and oxycodone $(20$ $\mu \mathrm{g} / \mathrm{mL}$ ) using $0.1 \mathrm{M} \mathrm{KH}_{2} \mathrm{PO}_{4}$ : acetonitrile of $\mathrm{pH} 5.5(70: 30$, v/v) as a mobile phase

Method validation: The developed HPLC method was validated as stated by the ICH guidelines [23] for system suitability, selectivity, linearity, precision, accuracy, robustness, limit of detection (LOD), limit of quantification (LOQ).

System suitability: The system suitability parameters $(\%$ RSD of retention time, \% RSD of peak area, USP plate count, 
USP resolution and USP tailing factor) were calculated after six replicate injections of standard naloxone and oxycodone solution into the HPLC system. The results are tabulated in Table-1 which is in the acceptable range.

Selectivity: To evaluate the specificity of the proposed method, chromatograms of place blank, mobile phase blank and tablet sample were compared with chromatogram of standard solution of naloxone and oxycodone. The chromatograms are shown in Figs. 4 and 5. No endogenous peak was observed at the retention time of naloxone and oxycodone in the chromatograms of placebo blank and mobile phase blank. The retention time of naloxone and oxycodone in chromatograms of tablet sample solution (Fig. 4) and standard solution (Fig. 5) are same. The common excipients of tablet dosage form and components of mobile phase did not interfere with the assay of selected drug combination and thus indicating the selectivity of the proposed method.

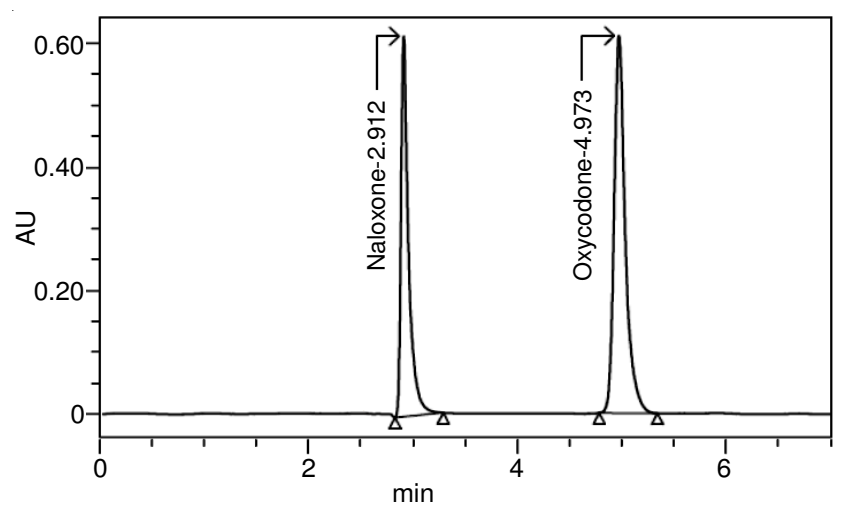

Fig. 4. Chromatogram of tablet sample solution (naloxone $-10 \mu \mathrm{g} / \mathrm{mL}$ and oxycodone - $20 \mu \mathrm{g} / \mathrm{mL}$ )

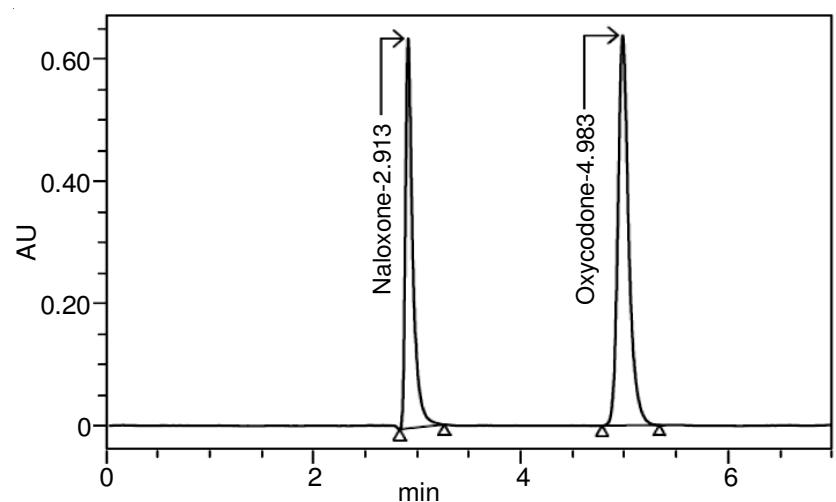

Fig. 5. Chromatogram of standard solution of (naloxone $-10 \mu \mathrm{g} / \mathrm{mL}$ and oxycodone - $20 \mu \mathrm{g} / \mathrm{mL}$ )
Linearity: A linear relationship was established by plotting the peak area against the drug concentration $(\mu \mathrm{g} / \mathrm{mL})$. The concentration range was found to be $5-15 \mu \mathrm{g} / \mathrm{mL}$ and $10-30 \mu \mathrm{g} / \mathrm{mL}$ for naloxone and oxycodone, respectively. Linear regression analysis of the data gave the following equations:

$$
\begin{aligned}
& Y=29571 c-1248\left(R^{2}=0.9999\right) \text { for naloxone } \\
& Y=21742 c+47.5\left(R^{2}=0.9999\right) \text { for oxycodone }
\end{aligned}
$$

where $\mathrm{Y}$ is the peak area, $\mathrm{c}$ is the concentration of the drug $(\mu \mathrm{g} / \mathrm{mL})$ and $\mathrm{R}^{2}$ is the regression coefficient. The high values of regression coefficients $(>0.999)$ with small intercept indicate the good linearity of the calibration curves for naloxone and oxycodone.

Limit of detection (LOD) and limit of quantification (LOQ): The smallest amount of drug (LOD) that could be detected was $3.750 \mu \mathrm{g} / \mathrm{mL}$ for naloxone and $3.860 \mu \mathrm{g} / \mathrm{mL}$ for oxycodone. The LOQs were $10.550 \mu \mathrm{g} / \mathrm{mL}$ and $10.410 \mu \mathrm{g} / \mathrm{mL}$ for naloxone and oxycodone, respectively. The low values of LOD and LOQ point out the adequate sensitivity of the proposed method for the quantification of naloxone and oxycodone.

Precision and accuracy: The proposed method was assessed by studying the accuracy as per cent recovery and precision as per cent relative standard deviation (\% RSD). Precision and accuracy was determined by analyzing standard solution of naloxone $(10 \mu \mathrm{g} / \mathrm{mL})$ and oxycodone $(20 \mu \mathrm{g} / \mathrm{mL})$ six times. The peak areas obtained were used to calculate mean recovery and $\%$ RSD. The results are shown in Table- 2 . The mean recovery and $\%$ RSD values indicate that the developed method could estimate naloxone and oxycodone with good accuracy and

\begin{tabular}{|c|c|c|c|c|}
\hline \multicolumn{5}{|c|}{$\begin{array}{c}\text { TABLE-2 } \\
\text { PRECISION AND ACCURACY DATA FOR THE } \\
\text { DETERMINATION OF NALOXONE AND } \\
\text { OXYCODONE BY THE PROPOSED METHOD }\end{array}$} \\
\hline \multirow{2}{*}{$\begin{array}{c}\text { Sample } \\
\text { No. }\end{array}$} & \multicolumn{2}{|c|}{ Naloxone $(10 \mu \mathrm{g} / \mathrm{mL})$} & \multicolumn{2}{|c|}{ Oxycodone $(20 \mu \mathrm{g} / \mathrm{mL})$} \\
\hline & Peak area & Recovery (\%) & Peak area & Recovery (\%) \\
\hline 1 & 2954197 & 99.43 & 4342803 & 99.19 \\
\hline 2 & 2958653 & 99.58 & 4341482 & 99.16 \\
\hline 3 & 2959513 & 99.61 & 4347175 & 99.29 \\
\hline 4 & 2950997 & 99.33 & 4342453 & 99.18 \\
\hline 5 & 2953886 & 99.42 & 4340411 & 99.14 \\
\hline 6 & 2954007 & 99.43 & 4345039 & 99.24 \\
\hline Mean & 2955411 & 99.474 & 4343312 & 99.202 \\
\hline RSD & 0.1210 & 0.1182 & 0.0635 & 0.0623 \\
\hline
\end{tabular}
precision, respectively.

Recovery studies: In recovery studies, known amount of

\begin{tabular}{|c|c|c|c|c|c|c|c|c|c|c|}
\hline \multicolumn{11}{|c|}{$\begin{array}{c}\text { TABLE-1 } \\
\text { RESULTS OF SYSTEM SUITABILITY STUDIES }\end{array}$} \\
\hline \multirow{2}{*}{$\begin{array}{l}\text { Sample } \\
\text { No. }\end{array}$} & \multicolumn{5}{|c|}{ Naloxone $(10 \mu \mathrm{g} / \mathrm{mL})$} & \multicolumn{5}{|c|}{ Oxycodone $(20 \mu \mathrm{g} / \mathrm{mL})$} \\
\hline & $\begin{array}{l}\text { Retention } \\
\text { time }\end{array}$ & $\begin{array}{l}\text { Peak } \\
\text { area }\end{array}$ & $\begin{array}{l}\text { Plate } \\
\text { count }\end{array}$ & $\begin{array}{l}\text { Tailing } \\
\text { factor }\end{array}$ & Resolution & $\begin{array}{l}\text { Retention } \\
\text { time }\end{array}$ & $\begin{array}{l}\text { Peak } \\
\text { area }\end{array}$ & $\begin{array}{l}\text { Plate } \\
\text { count }\end{array}$ & $\begin{array}{l}\text { Tailing } \\
\text { factor }\end{array}$ & Resolution \\
\hline 1 & 2.913 & 2945586 & 9960 & 1.71 & - & 4.983 & 4335011 & 11879 & 1.31 & 13.16 \\
\hline 2 & 2.92 & 2956314 & 9910 & 1.73 & - & 4.984 & 4334221 & 11891 & 1.31 & 13.18 \\
\hline 3 & 2.914 & 2979716 & 9922 & 1.73 & - & 4.977 & 4357864 & 11708 & 1.33 & 13.11 \\
\hline 4 & 2.92 & 2976090 & 9819 & 1.76 & - & 4.985 & 4335418 & 11789 & 1.33 & 13.1 \\
\hline 5 & 2.916 & 2923042 & 9920 & 1.74 & - & 4.980 & 4375040 & 11843 & 1.33 & 13.2 \\
\hline Mean & 2.917 & 2956149 & 9906 & 1.734 & - & 4.982 & 4347510 & 11822 & 1.322 & 13.150 \\
\hline RSD & 0.1127 & 0.7862 & 0.5282 & 1.0476 & - & 0.0657 & 0.4217 & 0.6349 & 0.8286 & 0.3315 \\
\hline Recommended limit & $\mathrm{RSD} \leq 2$ & $\mathrm{RSD} \leq 2$ & $>2000$ & $\leq 2$ & - & $\mathrm{RSD} \leq 2$ & $\mathrm{RSD} \leq 2$ & $>2000$ & $\leq 2$ & $>1.5$ \\
\hline
\end{tabular}
standard naloxone and oxycodone was spiked into preanalyzed 
TABLE-3

RECOVERY RESULTS FOR THE DETERMINATION OF NALOXONE AND OXYCODONE BY THE PROPOSED METHOD

\begin{tabular}{|c|c|c|c|c|c|c|c|c|}
\hline \multirow{2}{*}{$\begin{array}{c}\text { Spiked } \\
\text { level }(\%)\end{array}$} & \multicolumn{4}{|c|}{ Naloxone } & \multicolumn{4}{|c|}{ Oxycodone } \\
\hline & $\begin{array}{c}\text { Added } \\
(\mu \mathrm{g} / \mathrm{mL})\end{array}$ & $\begin{array}{c}\text { Found } \\
(\mu \mathrm{g} / \mathrm{mL})\end{array}$ & $\begin{array}{c}\text { Recovery } \\
(\%)\end{array}$ & $\begin{array}{c}\text { Mean } \\
(\%)\end{array}$ & $\begin{array}{c}\text { Added } \\
(\mu \mathrm{g} / \mathrm{mL})\end{array}$ & $\begin{array}{c}\text { Found } \\
(\mu \mathrm{g} / \mathrm{mL})\end{array}$ & $\begin{array}{c}\text { Recovery } \\
(\%)\end{array}$ & $\begin{array}{c}\text { Mean } \\
(\%)\end{array}$ \\
\hline \multirow{3}{*}{50} & 4.975 & 4.980 & 100.107 & \multirow{3}{*}{99.833} & 9.930 & 9.925 & 99.951 & \multirow{3}{*}{100.060} \\
\hline & 4.975 & 4.969 & 99.877 & & 9.930 & 9.946 & 100.165 & \\
\hline & 4.975 & 4.951 & 99.515 & & 9.930 & 9.936 & 100.064 & \\
\hline \multirow{3}{*}{100} & 9.950 & 9.957 & 100.069 & \multirow{3}{*}{100.097} & 19.860 & 19.847 & 99.932 & \multirow{3}{*}{99.905} \\
\hline & 9.950 & 9.962 & 100.117 & & 19.860 & 19.838 & 99.890 & \\
\hline & 9.950 & 9.960 & 100.104 & & 19.860 & 19.839 & 99.892 & \\
\hline \multirow{3}{*}{150} & 14.925 & 14.928 & 100.023 & \multirow{3}{*}{100.032} & 29.790 & 29.784 & 99.981 & \multirow{3}{*}{100.018} \\
\hline & 14.925 & 14.928 & 100.021 & & 29.790 & 29.804 & 100.046 & \\
\hline & 14.925 & 14.933 & 100.052 & & 29.790 & 29.798 & 100.028 & \\
\hline
\end{tabular}

TABLE-4

EFFECT OF FLOW RATE AND COLUMN TEMPERATURE ON THE SYSTEM SUITABILITY PARAMETERS

\begin{tabular}{|c|c|c|c|c|c|c|}
\hline \multirow{2}{*}{ Parameter } & \multicolumn{3}{|c|}{ Naloxone $(10 \mu \mathrm{g} / \mathrm{mL})$} & \multicolumn{3}{|c|}{ Oxycodone $(20 \mu \mathrm{g} / \mathrm{mL})$} \\
\hline & USP tailing & USP plate count & USP resolution & USP tailing & USP plate count & USP resolution \\
\hline Flow rate $1.0+0.1 \mathrm{~mL} / \mathrm{min}$ & 1.79 & 11340 & - & 1.43 & 13542 & 13.96 \\
\hline Flow rate $1.0-0.1 \mathrm{~mL} / \mathrm{min}$ & 1.76 & 8491 & - & 1.36 & 10699 & 12.49 \\
\hline Temperature $25+5^{\circ} \mathrm{C}$ & 1.80 & 11779 & - & 1.44 & 13369 & 13.96 \\
\hline Temperature $25-5^{\circ} \mathrm{C}$ & 1.76 & 8317 & - & 1.35 & 10580 & 12.38 \\
\hline
\end{tabular}

tablet sample solution at three concentration levels. The per cent recovery of naloxone and oxycodone was once again determined by the proposed method. The results are tabulated in Table- 3 . Recovery values (close to $100 \%$ ) indicate that the developed method was appropriate for accurate quantification of naloxone and oxycodone. Tablet excipients did not interference in the assay of naloxone and oxycodone.

Robustness: The effects of small changes in the flow rate of mobile phase $(1.0 \pm 0.1 \mathrm{~mL} / \mathrm{min})$ and column temperature $\left(25 \pm 5^{\circ} \mathrm{C}\right)$ on the system suitability parameters (USP plate count, USP resolution and USP tailing factor) were examined. The robustness of the method was determined at concentration of 10 $\mu \mathrm{g} / \mathrm{mL}$ for naloxone and $20 \mu \mathrm{g} / \mathrm{mL}$ for oxycodone. From the results (Table-4), it was found that the slight changes in flow rate and column temperature had no significant influence on the system suitability parameters, confirming the method robustness.

\section{Conclusion}

Naloxone and oxycodone in combined tablet dosage form has been determined using high performance liquid chromatographic method. The HPLC-PDA detector system with $\mathrm{C} 18$ analytical column $(250 \mathrm{~mm} \times 4.6 \mathrm{~mm}, 5 \mathrm{~mm}$, particle size $)$ was used in this study. Potassium dihydrogen phosphate $(\mathrm{pH}$ $5.5)$ and acetonitrile in the ratio of 70:30 (v/v) was chosen as the mobile phase with a flow rate of $1.0 \mathrm{~mL} / \mathrm{min}$ and a detection wavelength of $210 \mathrm{~nm}$. The HPLC method for the simultaneous quantification of naloxone and oxycodone was successfully developed and validated. The method was validated in terms of system suitability, linearity, sensitivity, accuracy, precision, selectivity and robustness. The results of the validation parameters were found to be within the acceptance limits.

\section{REFERENCES}

1. Naloxone Hydrochloride, The American Society of Health-System Pharmacists. Retrieved Jan 2, 2015.

2. S. Sirohi, S.V. Dighe, P.A. Madia and B.C. Yoburn, J. Pharmacol. Exp. Ther, 330, 513 (2009);

https://doi.org/10.1124/jpet.109.152678.
3. E.W. Boyer, N. Engl. J. Med., 367, 146 (2012); https://doi.org/10.1056/NEJMra1202561.

4. J. Riley, E. Eisenberg, G. Müller-Schwefe, A.M. Drewes and L. ArendtNielsen, Curr. Med. Res. Opin., 24, 175 (2008); https://doi.org/10.1185/030079908X253708.

5. R. Al-Hasani and M.R. Bruchas, Anesthesiology, 115, 1363 (2011); https://doi.org/10.1097/ALN.0b013e318238bba6.

6. T.R. Kosten and T.P. George, Sci. Pract. Perspect., 1, 13 (2002);

7. http://www.medscape.com/viewarticle/828812.

8. J. Poelaert, G. Koopmans-Klein, A. Dioh, F. Louis, M. Gorissen, D. Logé, J.V.O. den Bosch and Y.J. van Megen, Clin. Ther, 37, 784 (2015); https://doi.org/10.1016/j.clinthera.2015.02.010.

9. M.E., Gil-Alegre, M.L. Barone and A.L. Torres-Suárez, J. Sep. Sci., 28, 2086 (2005); https://doi.org/10.1002/jssc. 200400068 .

10. R. Panchagnula, P. Sharma, S. Khandavilli and M.V. Varma, IL Farmaco, 59, 839 (2004); https://doi.org/10.1016/i.farmac.2004.06.002.

11. R.W. Reid, A. Deakin and D.J. Leehey, J. Chromatogr. A, 614, 117 (1993); https://doi.org/10.1016/0378-4347(93)80230-2.

12. M.S. Tawakkol, M.E. Mohamed and M.M.A. Hassan, J. Liq. Chromatogr, 6. 1491 (1983); https://doi.org/10.1080/01483918308064866.

13. H. Jiang, Y. Wang, M.S. Shet, Y. Zhang, D. Zenke and D.M. Fast, J. Chromatogr. B, 879, 2663 (2011); https://doi.org/10.1016/j.jchromb.2011.06.039.

14. W.B. Fang, Y. Chang, E.F. McCance-Katz and D.E. Moody, J. Anal. Toxicol., 33, 409 (2009); https://doi.org/10.1093/jat/33.8.409.

15. A.W.E. Wright, J.A. Lawrence, M. Iu, T. Cramond and M.T. Smith, J. Chromatogr. B. Biomed. Sci. Appl., 712, 169 (1998); https://doi.org/10.1016/S0378-4347(98)00146-7.

16. E.M.S. Hannele and K.S. Piia, J. AOAC Int., 83, 1497 (2000).

17. F. Pantano, S. Brauneis, A. Forneris, R. Pacifici, E. Marinelli, C. Kyriakou, S. Pichini and F.P. Busardò, Clin. Chem. Lab. Med., 55, 1324 (2017); https://doi.org/10.1515/cclm-2016-0990.

18. O. Cheremina, I. Bachmakov, A. Neubert, K. Brune, M.F. Fromm and B. Hinz, Biomed. Chromatogr., 19, 777 (2005); https://doi.org/10.1002/bmc.516.

19. M. Neuvonen and P.J. Neuvonen, Ther. Drug Monit., 30, 333 (2008); https://doi.org/10.1097/FTD.0b013e31816e2d4b.

20. S.G. McKinley, J.J. Snyder, E. Welsh, C.M. Kazarian, M.H. Jamerson and K.L. Klette, J. Anal. Toxicol., 31, 434 (2007); https://doi.org/10.1093/jat/31.8.434.

21. B.A. Goldberger, C.W. Chronister and M.L. Merves, Methods Mol. Biol., 603, 245 (2010); https://doi.org/10.1007/978-1-60761-459-3 22.

22. A.B. Wey and W. Thormann, J. Chromatogr. B, 770, 191 (2002); https://doi.org/10.1016/S1570-0232(01)00568-2.

23. ICH Validation of analytical procedures; Text and methodology; Q2(R1), International Conference on Harmonization (2005). 